\title{
SYSTEMIC LUPUS ERYTHEMATOSUS WITH THROMBOCYTOPENIC PURPURA
}

\author{
By C. M. Ridley, M.A., B.M., M.R.C.P. \\ Senior Registrar, Skin Department, The London Hospital, E.I
}

This patient whose illness is reported below attended hospital complaining only of a rash on the legs. $\mathrm{He}$ was found to have systemic lupus erythematosus (S.L.E.) and thrombocytopenic purpura; treatment with steroids was ineffective but splenectomy resulted in a prompt return of the platelets to normal.

\section{Case Report}

The patient is a man of 44 , a collector of hirepurchase payments; he is of a cheerful and stoical disposition.

He was first seen in July 1957, complaining of a rash on the legs noticed for a few days. The rash was purpuric. The capillary fragility was not increased and there were no other abnormal clinical findings, apart from scattered bruises. Investigations, however, showed gross abnormalities with the platelets only 27,600 per cu. $\mathrm{mm}$. and the E.S.R. (Westergren) $105 \mathrm{~mm}$. in one hour, and he was admitted. He then owned to some bleeding of the gums and nose for two years, and to ' red marks' on the face, ears and backs of the hands, worse in winter, for two to three years. He had lost about a stone and a half in weight over the same time, but he had felt well. Two weeks before admission he had had an episode lasting for an hour when he had felt dazed and his right hand had been seen to twitch; he was unconscious for two hours, but had had no incontinence or tongue-biting. The only medicine taken was a proprietary tonic containing quinine and aspirin.

In the past he had had a right mastoidectomy in 1944; sulphonamide powder was put into the cavity afterwards. Penicillin injections were given for boils on two occasions during the three years before admission; there were no ill-effects. His mother died of a coronary thrombosis.

On examination he looked well. There was a fading purpuric rash on the lower legs and scattered bruises. The tip of the spleen could just be felt. There were small glands in the axillae and groins and signs of a right mastoidectomy. The blood pressure was $140 / 90 \mathrm{~mm}$. of mercury.
Investigations on admission showed a platelet count of 43,000 per cu. mm., a haemoglobin of 85 per cent. (12.6 g.) and a white cell count of 6,300 per cu. mm. (P. 80, L. I7, M. 2, B. I). The bleeding time was $2 \mathrm{~min}$. $40 \mathrm{sec}$. The E.S.R. (Westergren) was $5 \mathrm{I} \mathrm{mm}$. in one hour. Hess's test was negative.

The plasma proteins were $7.4 \mathrm{~g}$. $/ \mathrm{r} 00 \mathrm{ml}$.albumin $3.9 \mathrm{~g}$., globulin $3.5 \mathrm{~g}$. with no cryoglobulin. The blood urea was $36 \mathrm{mg}$. $/ 100 \mathrm{ml}$. The serum bilirubin was $0.5 \mathrm{mg}$. $/ 100 \mathrm{ml}$., the alkaline phosphatase 7.0 units; thymol turbidity 6.0 units. L.E. cells were present on two occasions. The W.R. was negative. Price's precipitation reaction was positive neat, the treponemal Wassermann reaction positive and the treponemal immobilization reaction negative. There was a calcified focus at the right apex in the chest X-ray.

A sternal puncture showed numerous megakaryocytes but none showing platelet formation or the normal granularity. A lumbar puncture produced yellow clear fluid at normal pressure with 6 cells/c. $\mathrm{mm}$., protein $50 \mathrm{mg}$./100 ml., chlorides $698 \mathrm{mg} . / 100 \mathrm{ml}$. A film showed occasional lymphocytes and culture was sterile.

An E.E.G. (Dr. G. Lyberi) showed the dominant frequency to be alpha rhythm but it was unstable and irregular, being diffusely mixed with theta activity. The latter seemed more prominent on the left than on the right. Short episodic discharges of slow waves of medium voltage occurred over the left temporal lobe. Mixed potentials of high voltage appeared on the right at the same time and may have masked similar findings there.

An E.C.G. showed low $\mathrm{T}$ waves in all leads; a few weeks later the $T$ waves had returned to normal.

Patch tests to procaine, quinine, soluble aspirin, carbromal and sedormid were all negative.

\section{Course}

Shortly after admission he had an episode of mental confusion, without abnormal physical signs, 


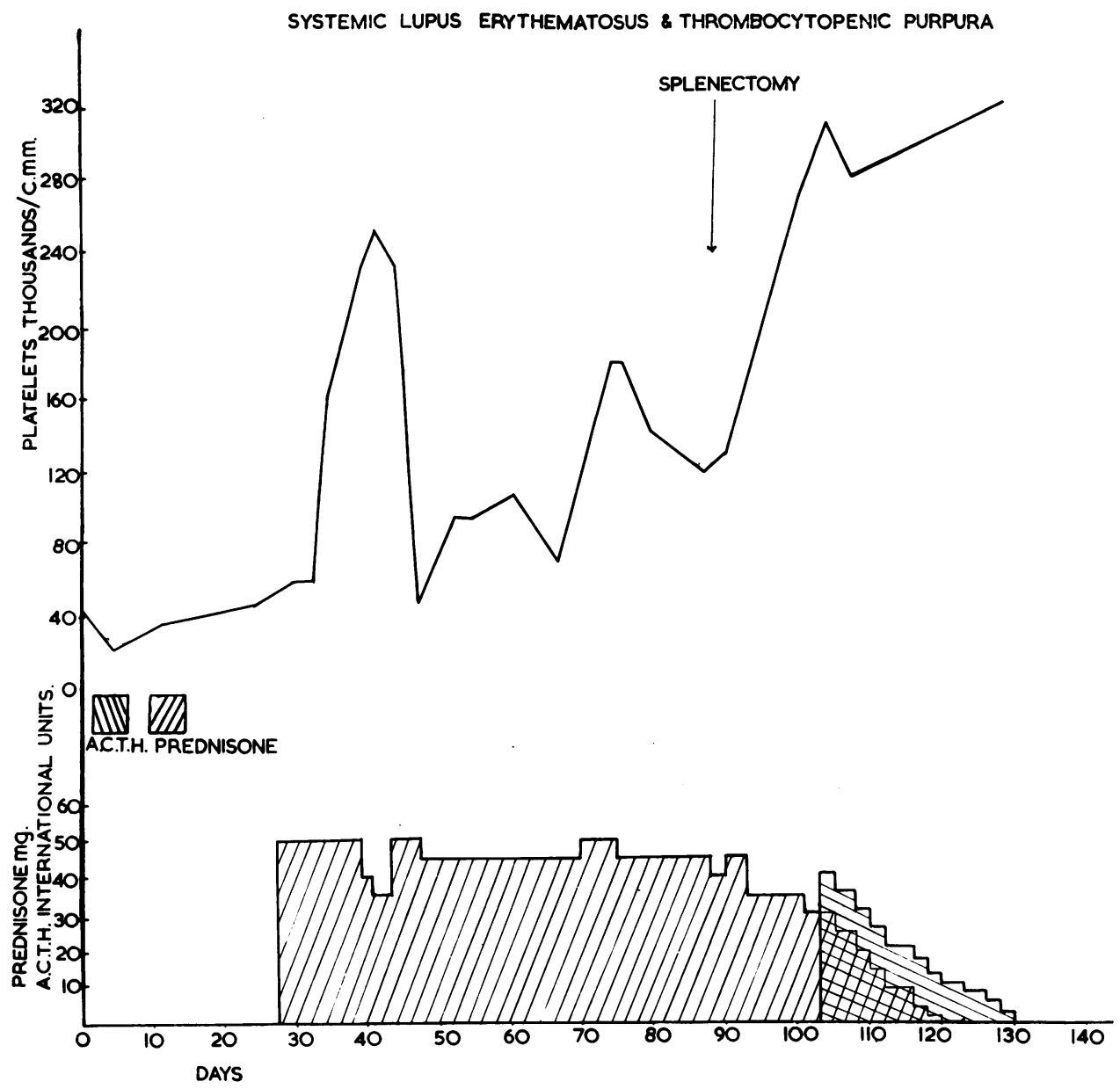

lasting for a few hours. Splinter haemorrhages developed under several finger nails, and haemorrhagic lesions on the palate, but the original purpura on the legs continued to fade. The temperature was raised to $100^{\circ}$ for a few days after admission, but thereafter remained normal. The urine occasionally showed a trace of albumin.

It was felt that bleeding because of the thromocytopenia was as likely a cause of the cerebral changes as the S.L.E. itself and in view of the persistently low platelet count (see diagram) prednisone was given. The total dose of prednisone before splenectomy was $2,770 \mathrm{mg}$. over 60 days. He had a diet with no added salt as well as alkalis and, later, testosterone.

During the treatment with prednisone he had occasional boils, transient and unexplained swelling round the jaw for a few mornings on waking, and one episode of epigastric pain relieved by vomiting. There was sacral oedema, although the weight remained virtually constant.

The patient thought that the bleeding of the gums was lessened by prednisone. There was no maintained improvement however in his platelet counts and it was decided to remove his spleen. The spleen was twice the normal size and on microscopic examination (Dr. A. Marshall) showed scanty foci of haemopoesis with some plasma cell infiltration, and a moderate increase of peri- of arterial connective tissue, some of which resembled $₹$ the onion skin fibrosis typical of L.E. The 을 platelets rose; details of the platelet counts in $>$ relation to prednisone and operation are given in the diagram.

Prednisone was gradually withdrawn and the platelets remained normal. ACTH was given at 0 the end of the course of prednisone. He received $\tilde{\omega}$ a course of tetracycline for a boil on the face. $\sigma$

Three weeks after splenectomy, when he wase still having prednisone, he had pain in the left $\bar{\varnothing}$ side of the chest and in the left arm. The blood $\stackrel{?}{+}$ pressure fell to $130 / 90 \mathrm{~mm}$. of mercury from a 0 level of $140 / 90$ to $160 / 100 \mathrm{~mm}$., and the next day a triple rhythm was heard. The E.C.G. showed 
further deterioration with inversion of $T$ waves in leads I and II and CR. 7, and lowering in CR. 4. His white cells rose to 29,500 per cu. mm. (polymorphs 76 per cent.). It was concluded that he had probably had a cardiac infarction and he was treated by a period of bed rest.

On discharge his platelets were normal and the E.S.R. (Westergren) 10 $\mathrm{mm}$. in one hour. One year after the splenectomy he continues to feel well. Some mottled erythema on the hands, ulcerated in cold weather, has appeared; there are erythematous patches on the face.

Investigations three months after discharge showed a haemoglobin of 104 per cent. (15.4 g.) and a white cell count of 8,100 per cu. mm. (P. 42, L. 49, M. 9); the platelets looked normal on the blood film and a short time previously were 320,000 per cu. mm. The E.S.R. (Westergren) was $17 \mathrm{~mm}$. in one hour. The bilirubin was 1.0 mg./100 cc., the alkaline phosphatase 1o King Armstrong units per cent. and the thymol turbidity 4.6 units per cent. The plasma proteins were $8.6 \mathrm{~g}$. $/$ $00 \mathrm{ml}$. (albumin $5.7 \mathrm{~g}$., globulin $2.9 \mathrm{~g}$.) No L.E. cells could be found. The platelets have since remained normal. The E.S.R. has fallen to $7 \mathrm{~mm}$. in one hour.

An E.E.G. (Dr. G. Lyberi) showed a normal, stable and symmetrical alpha rhythm, remaining normal in response to overbreathing and photic stimulation; no theta activity was present.

\section{Discussion}

This patient had S.L.E. and thrombocytopenic purpura. The thrombocytopenic purpura did not respond adequately to steroids but has remitted so far following a splenectomy, although signs of the S.L.E. remain. The improvement in his E.E.G. may or may not be significant, since the cause of the original abnormality could have been the vascular changes of S.L.E. or bleeding secondary to the thrombocytopenic purpura. Cohen and Cadman (1953) record changes for the better in their patients' E.E.G.s when the S.L.E. improved.

The literature describing the association of various blood changes with S.L.E. has been reviewed by Harvey et al. (1954). The combination of S.L.E. and thrombocytopenic purpura is well recognized. S.L.E. with thrombocytopenic purpura where there was a circulating anticoagulant and hypothrombinaemia has also been described (Bonnin et al., 1956).

Several authors have pointed out that at the time when the thrombocytopenic purpura is evident there may be no evidence of S.L.E.; this is true even when evidence of S.L.E. is assiduously sought, as shown by the cases of Dameshek and Reeves (1956) and Eversole (1955). Eversole emphasizes that S.L.E. may be suspected only on examining the spleen for the onion skin fibrosis described by Klemperer et al. in 194I and believed to be a sure sign of S.L.E. if well marked (though it need not always be present in S.L.E. and may occur in the absence of thrombocytopenic purpura), or at autopsy, or by following the patient for some years.

Almost certainly too, many cases have been missed by failing to recognize the possibility of S.L.E. when confronted by a patient who has thrombocytopenia.

In view of the evidence surveyed by Honey (I956) that S.L.E. may be closely associated with drug reactions, there is also a possibility that some patients with thrombocytopenic purpura seeming to result from sensitivity to a drug may in reality have S.L.E. or later develop it. It would be informative if L.E. cells were looked for in such cases and if the patients were followed carefully afterwards.

In treating the thrombocytopenic purpura in patients with S.L.E. the two chief agents are steroids and the removal of the spleen.

Harvey et al. (1954) in their comprehensive review of S.L.E. surveyed 13 cases from the literature and nine of their own where thrombocytopenic purpura was a prominent feature. Thirteen cases had a splenectomy, and in all the platelets rose promptly afterwards. One patient was treated with ACTH and cortisone; the platelets rose, but relapsed when the therapy was withdrawn, and failed to rise in a second course; splenectomy was not done. In another ACTH had no beneficial effect but the platelets rose at once after splenectomy.

Stefanini (1955) says that in the thrombocytopenic purpura associated with S.L.E. steroids usually have a good effect at first, but that the platelets may later fall, and that splenectomy may be useful.

Conley (1955) says, in a general account, that ACTH and cortisone have produced a transient rise of platelets in some cases, but that splenectomy has been uniformly effective; in most of the cases there has been no recurrence of the thrombocytopenic purpura even if death from S.L.E. ultimately occurs.

Eversole (1955) describes six patients who had S.L.E. but were diagnosed originally as thrombocytopenic purpura. All but one of these patients had been included in the list of Harvey et al. (1954). The remaining patient had a splenectomy but was not followed up. $\mathrm{He}$ concludes that the presence of S.L.E., if known, need not contra-indicate splenectomy.

Dubois (1956) in his survey of the une of 
steroids in treating S.L.E. does not mention thrombocytopenic purpura.

Eller (1956) in a general account says that splenectomy is usually followed by a sustained rise in the platelets.

Dameshek and Reeves (1956) reported one case of thrombocytopenic purpura and two of autoimmune haemolytic anaemia. In each, initial proof of S.L.E. was sought in vain and each had a splenectomy after treatment with steroids. Later clinical manifestations of S.L.E. developed, L.E. cells being found. The authors suggest that the splenectomy may in some way remove an inhibiting influence on the S.L.E. Clearly it is difficult definitely to establish this point. In a further paper (Dameshek et al., I 955) it is said that approximately 25 per cent. of all patients with apparently typical thrombocytopenic purpura in whom the spleen is removed will eventually develop S.L.E.; no details are given of the clinical course.

It seems that in no recorded case has the thrombocytopenic purpura associated with S.L.E. been satisfactorily controlled by steroids. The published cases are however too few for any definite conclusion to be drawn from them.

\section{Summary}

The case history of a man with systemic lup erythematosus in whom thrombocytopenic puspura was a prominent feature is described. The thrombocytopenic purpura did not respond to prednisone but remitted after splenectomy. Sorße points of interest arising out of the case ase discussed.

I thank several colleagues for reports on spectal investigations and help in their interpretation. I am very grateful to Dr. Brian Russell, undsir whose care the patient was admitted, for his hedp and encouragement.

\section{BIBLIOGRAPHY}

BONNIN, J. A., COHEN, A. K., and HICKS, N. D. (1056) Brit. F. Haemat., 2, 168.

COHEN, H., and CADMAN, E. F. B. (1953), Lancet, ii, 305.

CONLEY, C. L. (1955), Bull. Rheumat. Dis., 5, 87.

DAMESHEK, W., and REEVES, W. H. (1956), Amer. F. MEt,

DAMESHEK, W., RUBIO, F., MAHONEY, J. P., REEV W. H., and BRIDGIN, L. A. (1958), Ұ. Amer. med. A . 166, 1805

DUBOIS, E. L. (1956), f. Amer. med. Ass., 161, i, 427.

ELLER, M. (1956), N.Y. St. F. Med., 56, ii, 3009.

EVERSOLE, S. L. (1955), fohns Hopk. Hosp. Bull., 96, 210.

HARVEY, A. M., SHULMAN, L. E., TUMULTY, P. \& CONLEY, C. L., and SCHOENRICH, E. H.' (1954) Medicine (Baltimore), 33, $29 \mathrm{I}$.

HONEY, M. (1956), Brit. med. Ұ., i, 1272.

LAZLO, M. H., ALVAREZ, A., and FELDMAN, F. (1959) Ann. intern. Med., 42, 1308.

SEIGAL, B. M., FREIDMAN, J. A., KESSLER, S., ค SCHWARTZ, S. O (1957), Ann intern Med 47, IO22,

STEFANINI, M. (1955), Arch. intern. Med., 95, 543.

\section{E. \& S. LIVINGSTONE, LTD}

A Contribution to the Study of

PORTAL HYPERTENSION

$$
\text { By }
$$

ALAN H. HUNT

M.A., D.M., M.Ch., F.R.C.S.

244 pages.

205 illustrations.

40s.

"A record which must be read by all who are interested in this subject. It is excellently produced, and the illustrations, particularly the radiographs, could not be better."-British Medical Journal.

"A most valuable addition to the literature of portal hypertension, both for the physician and surgeon. It deals with all aspects of the problem in the clearest possible manner and of particular merit are the studies of the pathological anatomy in the portal circulation. This is a most rewarding account of an extensive experience and one to which repeated reference will be made by all engaged in this field." Australian and New Zealand Journal of Surgery.

\section{SURGERY OF THE COLON}

By E. S. R. HUGHES, M.D.(Melb.), M.S.(Melb.), F.R.C.S.(Eng.), F.R.A.C.S.

424 pages. 339 illustrations.

63s.

TUMOURS OF THE BLADDER

Edited by D. M. WALLACE, O.B.E., M.S., F.R.C.S.

364 pages. 249 illustrations.

60s.

CELL AND tissue CULTURE

By JOHN PAUL, M.B., Ch.B., Ph.D., M.R.C.P.Ed.

269 pages. 102 illustrations.

30s.

\section{STAPHYLOCOCCUS PYOGENES AND ITS RELATION TO DISEASE}

By STEPHEN D. ELEK, M.D., D.Sc., Ph.D., D.P.H.

775 pages. 81 illustrations.

$84 s$.

MANUAL OF CHEST CLINIC PRACTICE IN TROPICAL AND SUB-TROPICAL COUNTRIES BY A. J. BENATT, M.D.

108 pages. 8 illustrations.

10s. 6d.

\section{CARCINOMA OF THE LUNG}

Edited by J. R. BIGNALL, M.A., M.D., M.R.C.P. 310 pages. 69 illustrations. 